\title{
Pearls of plastics in ENT practice that Conceals \& Camouflages the Camber, Contour \& Cosmesis in Facial Trauma
}

\section{Sphoorthi Basavannaiah}

Associate Professor, Department of ENT, Subbaiah Institute of Medical Sciences, NH-13, Purle, Holebenavalli Post, Shimoga- 577222, Karnataka, India.

Corresponding Author: Sphoorthi Basavannaiah, Department of ENT, Subbaiah Institute of Medical Sciences, NH-13, Purle, Holebenavalli Post, Shimoga- 577222, Karnataka, India

Received date: October 22, 2021: Accepted date: December 15, 2021: Published date: January 04, 2022

Citation: Sphoorthi Basavannaiah (2022) Pearls of Plastics in ENT practice that conceals \& camouflages the camber, contour \& cosmesis in facial trauma, Journal of Clinical Otorhinolaryngology 4(1); DOI: 10.31579/2692-9562/040

Copyright: ( ) 2022, Sphoorthi Basavannaiah. This is an open access article distributed under the Creative Commons Attribution License, which permits unrestricted use, distribution, and reproduction in any medium, provided the original work is properly cited.

Abstract
Facial trauma can involve soft tissue injuries such as burns, lacerations, bruises and even fractures of the facial
bones such as nasal fractures and fractures of the jaw as well as injury to the eye. Symptoms are specific to
the type of injury that can be either signs of inflammation or changes in facial definition. Facial injuries have
the potential to cause temporary deviations in facial delineation to permanent disfigurement of facial
structures.
Key words: facial trauma, contour, facial soft tissue injury, cosmesis

\section{Introduction}

Traumatic facial soft tissue injuries are commonly encountered in the emergency department by multi- speciality departments. Although rarely life-threatening, the treatment of these injuries can be complex and may have significant impact on the patient's facial function and aesthetics. These kind of time-testing cases are predominantly dealt by Otolaryngologists, Plastic surgeons and Maxillo-facial surgeons [5]. Hence, dealing such simple looking cases with its varied complexities shows the connotation and implication of practising and prioritising plastics in ENT in future which forms the major basis of preserving and conserving the facial cosmesis, camber and contour in patients. Here, are 2 such cases of facial soft tissue injury that were come across at the Emergency department at Tertiary care hospital, Shimoga.

\section{Case report:}

\section{Case-1}

7 year old boy with trauma to the nose while playing presented to the emergency department with bleeding from the nose and through-and through lacerated wound over the nose. The pictures of the same are shown below. The grandfather who had accompanied the boy was very happy looking at the results of suturing and had accolade me for my work and being enduring and persistent with the patient while suturing under local anaesthesia. But, the patient lost to follow up after the suturing. 


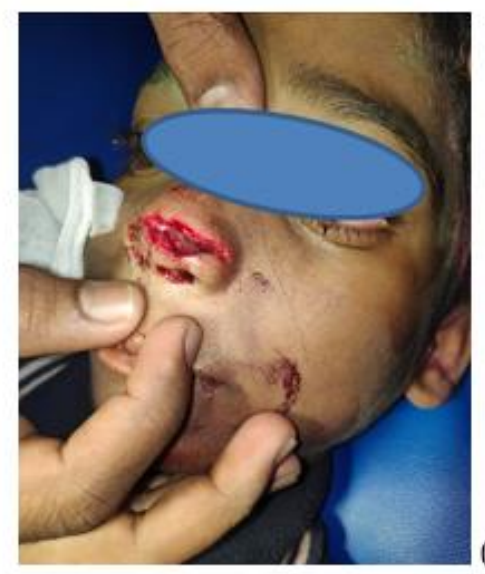

(a)

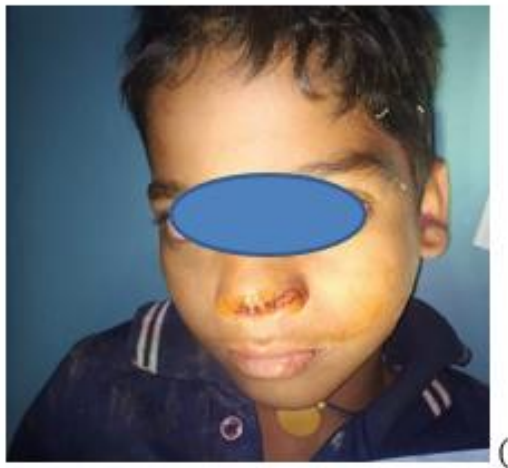

(c)
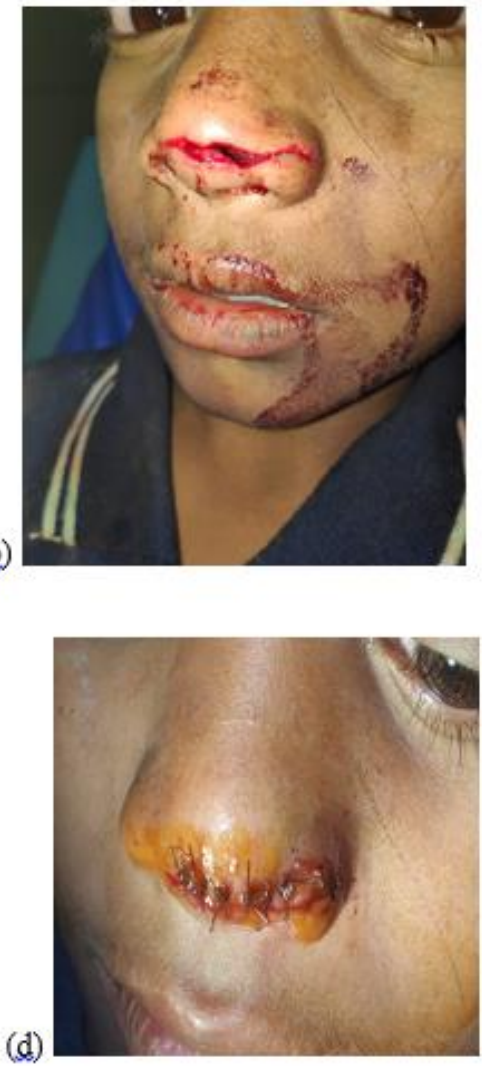

Figure a to d: $a \& b$ shows cut through lacerated wound about $2 \mathrm{cms}$ at the level of the dorsum of the nose also involving the anterior part of septal cartilage. $c \& d$ shows the closure of the lacerated wound.

\section{Case 2}

19 year old adult female reported to the emergency department with trauma just below the chin while fall from a 2 wheeler while riding. She presented with bleeding from this deep soft tissue injury which almost seems like a " injured open mouth with lips ". The patient was very worried regarding the cosmesis of the wound and had less tolerance to pain threshold, as she was a young unmarried girl. The patient followed up after 15 days for suture removal. She was very happy after seeing the desired outcome and thanked me for assuring her enough about the consequence before- hand while suturing the wound under local anaesthesia. The pictures of both before and after the soft tissue injury are shown below.
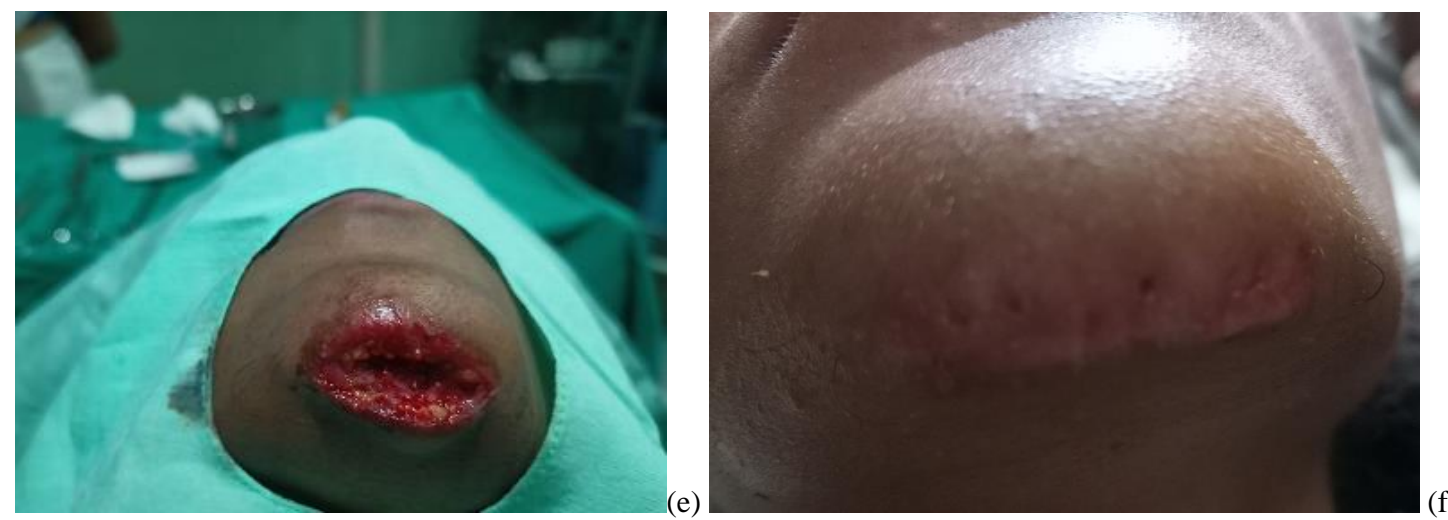

Figure a to d: $a \& b$ shows cut through lacerated wound about $2 \mathrm{cms}$ at the level of the dorsum of the nose also involving the anterior part of septal cartilage. $c \& d$ shows the closure of the lacerated wound.

Both these patients were quite an experience to me personally which not just tested my skills as a surgeon, my patience levels in handling such apprehensive and anxious patients and my convincing abilities to keep them calm and composed so as to have a smooth process of wound closure.

\section{Discussion:}

Facial trauma/ Maxillo-facial trauma is any kind of physical trauma to the face. Facial injuries have the potential to cause disfigurement and loss of function. Although it is seldom life-threatening, facial trauma can also be deadly, because it can cause severe bleeding or interference with airway; hence the primary concern is ensuring that the airway is open and not threatened so that the patient can breathe $[1,7]$. Depending on the type of facial injury, treatment may include suturing of open wounds, symptomatic treatment of the injury, set the fracture right with reduction after confirmation with radiography and even surgery at times. Treatment necessitates to be early and urgent when there is traumatic brain injury, which usually accompanies severe facial trauma [2]. 
Traumatic facial soft tissue injuries are commonly encountered in the emergency department by Otolaryngologists, Plastic and Maxillo-facial surgeons. The main etiology are road-traffic accidents (RTA's), while playing (sports injury), and these days even domestic violence have taken a toil as part of facial trauma. By itself, facial trauma rarely presents a threat to life but however it is often associated with dangerous injuries and life-threatening complications such as blockage of airway [3]. The airway can be blocked due to bleeding, edema and damage to surrounding tissues and structures. Burns to the face can cause swelling of tissues and thereby lead to airway blockage. Broken bones such as combinations of nasal, maxillary, and mandibular fractures can interfere with the airway. Blood from face/ nose/mouth, if swallowed causes vomiting which presents a threat to the airway as it can be aspirated. Since airway problems can occur late after the initial injury, it is necessary for healthcare providers to monitor the airway regularly [11].

Facial fractures are dispersed in a fairly normal curve by age, with a peak incidence between 20-40 years of age and in children $<12$ years of age only suffer 5-10\% of all facial fractures. Most facial trauma in children involves lacerations and soft tissue injuries. There are several reasons for the lower incidence of facial fractures in children [4, 13].The face is smaller in relation to rest of the head, children are less often in situations associated with facial fractures such as occupational and motor vehicle hazards, lower proportion of cortical bone to cancellous bone in children's faces, poorly developed sinuses make the bones stronger and fat pads provide protection for the facial bones. Head and brain injuries are commonly associated with facial trauma, particularly that of the upper face; brain injury occurs in $15-48 \%$ of people with maxillofacial trauma. People with trauma above the level of the collar bones are considered to be at high risk for cervical spine injuries and special precautions must be taken to avoid movement of the spine, which could worsen a spinal injury [12].

Even when facial injuries are not life-threatening, they have the potential to cause disfigurement and disability, with long-term physical and emotional results. Facial injuries can cause problems with eye, nose, or jaw function and can threaten eyesight. As early as 400 BC, Hippocrates is thought to have recorded a relationship between blunt facial trauma and blindness. Injuries involving the eye or eyelid, such as retrobulbar hemorrhage, can threaten eyesight; however, blindness following facial trauma is not common [10].

Although rarely life-threatening, the treatment of these injuries can be complex and may have significant impact on the patient's facial function and aesthetics. The injury are accompanied with bleeding (if nose, then nasal packing is must), from the wound (suturing under aseptic precautions under coverage of tetanus immunisation, from the fractures (open or close reduction and internal fixation with metal plating, wiring, screws with bone grating at times needed figuring out the entrapped nerves and muscles if any) [6].

Treatment aims to repair the face's natural bony architecture and to leave as little apparent trace of the injury as possible. An immediate need in treatment is to ensure that the airway is open and not threatened by tissues or foreign objects that leads to airway compromise. This compromise can occur rapidly and insidiously and is potentially deadly and at times supported with supplemental oxygen. Facial fractures that threaten to interfere with the airway can be sorted by reducing the fractures which both reduces bleeding and secures the airway $[8,11]$. If facial injuries prevent orotracheal or nasotracheal intubation, a surgical airway can be placed to provide an adequate airway by cricothyrotomy and tracheostomy. These are done as last resort because of potential complications and the difficulty of the procedures. The literature suggests that early repair of facial injuries within hours or days results in better outcomes for function and appearance [9].

About 50-70\% of people who survive road traffic accidents have facial trauma. In most developed countries, violence has replaced vehicle collisions as the main cause of maxillofacial trauma. However, in many developing countries road traffic accidents remain the major cause.
Increase use of seat belts and airbags have been credited with a reduction in the incidence of maxillofacial trauma, but fractures of mandible are not reduced by these protective measures $[3,9]$. The risk of maxillofacial trauma have been decreased with use of motorcycle helmets by not just the rider but also the pillion rider. A decline in facial bone fractures due to vehicle accidents is thought to be due to seat belt and drunk- driving laws, strictly enforced speed limits and use of airbags. In vehicle accidents, drivers and front seat passengers are at highest risk for facial trauma [2, 7].

Measures to reduce facial trauma include laws enforcing seat belt usage and public education to increase awareness about the importance of seat belts and motorcycle helmets. Efforts to reduce drunk driving as well as changes to societal attitudes toward the activity are other preventative measures. Information obtained from biomechanics studies can be used to design automobiles with a view toward preventing facial injuries $[5,8]$. While seat belts reduce the number and severity of facial injuries that occur in crashes, airbags alone are not very effective at preventing the injuries. In sports, safety devices including helmets have been found to reduce the risk of severe facial injury. Additional attachments such as face guards may be added to sports helmets to prevent orofacial injury [12].

\section{Conclusion:}

Soft tissue injuries whether isolated or in combination with other injuries are among the most common traumatic craniofacial injuries encountered by emergency department. These injuries account for nearly $10 \%$ of all emergency department visits. Despite this high incidence, there are few studies that methodically inspect the management of these injuries and therefore there is no widely accepted classification system or treatment processes exist to guide evaluation and treatment. As a result, most critical management choices are left solely to the decision of the treating surgeon with limited prospective or retrospective data, beyond personal experience which are available to guide treatment. This may lead to many incongruent approaches to both short-term and long-term management.

Take home message- Hence, this study also has tried to throw light on the need to provide essential and equal emphasis to the ENT practitioners towards "Facial Aesthetics \& Plastics" as they are very much proficient, expert and experienced in skilful exposures of any emergency posed at them any given point of time. Therefore, this must include of super-speciality aspect of "aesthetics \& plastics in ENT" will open doors to the innovative, creative and inventive "fifth wing" of this speciality of Otorhinolaryngology and Head \& Neck Surgery.

\section{References:}

1. Borzabadi-Farahani A, Borzabadi-Farahani A. The association between orthodontic treatment need and maxillary incisor trauma, a retrospective clinical study. Oral Surgery, Oral Medicine, Oral Pathology, Oral Radiology, and Endodontics. December 2011. 112 (6): e75-80.

2. Borzabadi-Farahani A, Borzabadi-Farahani A, Eslamipour F. An investigation into the association between facial profile and maxillary incisor trauma, a clinical non-radiographic study. Dental Traumatology. October 2010. 26 (5): 403-8.

3. Perry M. Advanced Trauma Life Support (ATLS) and facial trauma: can one size fit all? Part 1: dilemmas in the management of the multiply injured patient with coexisting facial injuries". International Journal of Oral and Maxillofacial Surgery. March 2008. 37 (3): 209-14.

4. Perry M, Morris C. Advanced trauma life support (ATLS) and facial trauma: can one size fit all? Part 2: ATLS, maxillofacial injuries and airway management dilemmas. International Journal of Oral and Maxillofacial Surgery. April 2008. 37 (4): 309-20.

5. Perry M, O'Hare J, Porter G. Advanced Trauma Life Support (ATLS) and facial trauma: can one size fit all? Part 3: Hypovolaemia and facial injuries in the multiply injured 
patient. International Journal of Oral and Maxillofacial Surgery. May 2008. 37 (5): 405-14.

6. Jordan JR, Calhoun KH. Management of soft tissue trauma and auricular trauma. In Bailey BJ, Johnson JT, Newlands SD, et al. (eds.). Head \& Neck Surgery: Otolaryngology. 2 Hagerstwon, MD: Lippincott Williams \& Wilkins. 2006. pp. 935-36.

7. McIntosh AS, McCrory P. Preventing head and neck injury. British Journal of Sports Medicine. June 2005. 39 (6): 314-18.

8. Perry M, Dancey A, Mireskandari K, et al. Emergency care in facial trauma: A maxillofacial and ophthalmic perspective". Injury. August 2005. 36 (8): 875-96.

9. Adeyemo WL, Ladeinde AL, Ogunlewe MO, et al. Trends and characteristics of oral and maxillofacial injuries in Nigeria: A review of the literature. Head \& Face Medicine. October 2005. 1 (1): 7.

10. Parks SN. Initial assessment. In Moore EE, Feliciano DV, Mattox KL (eds.). Trauma. Fifth Edition. McGraw-Hill Professional. 2003. p. 162.

11. Munter DW, McGurk TD. Head and facial trauma. In Knoop KJ, Stack LB, Storrow AB (eds.). Atlas of emergency medicine. New York: McGraw-Hill, Medical Publishing Division. 2002. pp. 9-10.

12. Allsop D, Kennett K. Skull and facial bone trauma. In Nahum $\mathrm{AM}$, Melvin $\mathbf{J}$ (eds.). Accidental injury: Biomechanics and prevention. Berlin: Springer. 2002. pp. 254-258.

13. Shapiro AJ, Johnson RM, Miller SF, et al. Facial fractures in a level I trauma centre: the importance of protective devices and alcohol abuse. Injury. June 2001.32 (5): 353-56.
This work is licensed under Creative Commons Attribution 4.0 License
DOI: $10.31579 / 2692-9562 / 040$
Ready to submit your research? Choose Auctores and benefit from:

$>$ fast, convenient online submission

$>$ rigorous peer review by experienced research in your field

$>$ rapid publication on acceptance

$>$ authors retain copyrights

$>$ unique DOI for all articles

$>$ immediate, unrestricted online access

At Auctores, research is always in progress.

Learn more https://auctoresonline.org/journals/journal-of-clinicalotorhinolaryngology 